\title{
Motivacija in zadovoljstvo z življenjem pri zaposlenih $v$ javnem in zasebnem sektorju
}

UDK: $316.628(045)$

\author{
Julija Peklar \\ Ministrstvo za obrambo RS \\ julija.peklar@mors.si \\ Eva Boštjančič \\ Univerza v Ljubljani, Filozofska fakulteta \\ eva.bostjancic@ff.uni-lj.si
}

\section{IZVLEČEK}

Delovna motivacija je usmerjanje človekove aktivnosti $k$ želenim ciljem, $\mathbf{s}$ pomočjo njegovih motivov, nastalih $v$ človekovi notranjosti ali $v$ njegovem okolju, na podlagi njegovih potreb. Namen raziskave je bil preveriti, ali se zaposleni razlikujejo $v$ vrsti delovne motivacije glede na sektor, delovno mesto, spol in izobrazbo ter kako se različni tipi motivacije povezujejo z zadovoljstvom z življenjem.

$\mathrm{V}$ raziskavi je sodelovalo 288 zaposlenih - $153 \mathrm{v}$ zasebnem in $116 \mathrm{v}$ javnem sektorju (19jih tega ni označilo). Rezultati so pokazali, da je pri vseh zaposlenih najbolj izražena notranja motivacija, da med sektorjema ni prišlo do razlik pri nobenem tipu motivacije ter da med vodji v javnem in zasebnem sektorju ni prišlo do statistično pomembnih razlik ne v zunanji motivaciji, ne v notranji motivaciji in ne v zadovoljstvu z življenjem.

Ključne besede: zunanja motivacija, notranja motivacija, teorija samodoločenosti, zadovoljstvo z življenjem, javni sektor, zasebni sektor

JEL: J24

\section{Uvod}

Že vrsto let se na področju organizacijske psihologije tako raziskovalci kot tudi vodje v organizacijah ukvarjajo z raziskovanjem in možnostmi vplivanja na delovno motivacijo. Najpomembnejšo vlogo pri motiviranju imajo prav nadrejeni (vodje), ki svoje zaposlene usmerjajo, poslušajo in nagrajujejo. 


\subsection{Javni in zasebni sektor}

Po podatkih Statističnega urada Republike Slovenije je bilo julija 2010 v zasebnem sektorju zaposlenih 645.351 ljudi, v javnem sektorju pa 259.195 ljudi (SURS). Opredelitev javnega sektorja, tudi v smislu ločitve od zasebnega, ni enotna ne v zakonodaji, ne v teoriji. Različni avtorji in tudi slovenski zakoni opredeljujejo javni sektor različno, definicije zasebnega sploh ni. V tej raziskavi smo se odločili, da bomo javni sektor opredelili tako, kot ga opredeljujeta zakon o sistemu plač in zakon o javnih uslužbencih. Vanj smo torej uvrstili: državno upravo, lokalne skupnosti, zdravstvo, šolstvo, kulturo, socialno varstvo, šport, znanost, sodstvo, vojsko, policijo. V zasebni sektor pa smo uvrstili vse panoge gospodarstva in samostojnega podjetništva.

\subsection{Delovna motivacija}

Motivi sprožajo z delom povezana vedenja ter določajo njegovo obliko, smer, intenzivnost in trajanje (Pinder, 1998, v Tremblay, Blanchard, Taylor, Pelletier \& Villeneuve, 2009). Delavčeva aktivnost je vedno odvisna od notranjih pobud ali zunanjih dražljajev (motivov) in ta gibala delavčeve aktivnosti imenujemo motivacija. Motiviranje pa je proces spodbujanja delavcev z določenimi sredstvi, da bodo le-ti učinkovito in z lastnim pristankom opravili dane naloge ali delovali v smeri določenih ciljev (Uhan, 2000). Znanih je veliko motivacijskih teorij, ki skušajo pojasniti problematiko motivacije, v naši raziskavi pa smo se osredotočili na teorijo samodoločenosti.

\subsection{Teorija samodoločenosti}

Teorija samodoločenosti (TSD; angl. Self-determination theory) poudarja pomembnost človekovih notranjih nagnjenj in psiholoških potreb, ki so osnova za samomotivacijo in integracijo osebnosti (Ryan \& Deci, 2000). Samodoločenost je definirana kot izkušnja opravljanja aktivnosti oz. vedenja iz avtonomnih, notranjih razlogov, ki jih v celoti podpira self, in ki so nasprotne razlogom, ki dajejo občutek pritiska ali prisile (Deci \& Ryan, 2000). Teorija predpostavlja, da ima vsak posameznik naravno, notranjo in konstruktivno težnjo k razvijanju še bolj izdelanega in enotnega občutka selfa (Ryan \& Deci, 2004).

TSD je zmožna identificirati različne tipe motivacij, od katerih ima vsaka po svoje specifične posledice na učenje, dosežke, osebne izkušnje in dobro počutje (Ryan \& Deci, 2000). Te tipe motivacije lahko razporedimo vzdolž kontinuuma samodoločenosti, ki predstavlja stopnjo, do katere so cilji oz. vrednote ponotranjene. Izraz notranja motivacija pomeni opravljanje aktivnosti zaradi nje same, z namenom osebnega zadovoljstva, zunanja motivacija pa opravljanje naloge iz instrumentalnih razlogov. 
Slika 1: Kontinuum samodoločenosti, ki prikazuje tipe motivacije ter njihove regulatorne stile in regulatorne procese

\begin{tabular}{|c|c|c|c|c|c|c|}
\hline Vedenje & \multicolumn{5}{|l|}{$\begin{array}{l}\text { Ne- } \\
\text { samodoločeno }\end{array}$} & $\begin{array}{l}\text { Samo- } \\
\text { določeno }\end{array}$ \\
\hline Motivacija & Amotivacija & & Zunanj & motivacija & & Notranja \\
\hline $\begin{array}{l}\text { Regulatorni } \\
\text { stil }\end{array}$ & Ni regulacije & $\begin{array}{l}\text { Zunanja } \\
\text { regulacija }\end{array}$ & $\begin{array}{l}\text { Introjekcijska } \\
\text { regulacija }\end{array}$ & $\begin{array}{l}\text { Identifikacijska } \\
\text { regulacija }\end{array}$ & $\begin{array}{l}\text { Integrirana } \\
\text { regulacija }\end{array}$ & $\begin{array}{l}\text { Notranja } \\
\text { regulacija }\end{array}$ \\
\hline $\begin{array}{l}\text { Relevantni } \\
\text { regulatorni } \\
\text { procesi }\end{array}$ & $\begin{array}{l}\text { Brez namere, } \\
\text { pomanjkanje } \\
\text { kontrole, brez } \\
\text { vrednotenja, } \\
\text { nekompe- } \\
\text { tentnost }\end{array}$ & $\begin{array}{l}\text { Ugoditev, } \\
\text { zunanje } \\
\text { pohvale in } \\
\text { kazni }\end{array}$ & $\begin{array}{l}\text { Samo- } \\
\text { kontrola, } \\
\text { vključevanje } \\
\text { ega, notranje } \\
\text { nagrade in } \\
\text { kazni }\end{array}$ & $\begin{array}{l}\text { Osebna } \\
\text { pomembnost, } \\
\text { vrednota, } \\
\text { zavestno } \\
\text { vrednotenje }\end{array}$ & $\begin{array}{l}\text { Kongruenca } \\
\text { zavedanj, } \\
\text { sinteza s } \\
\text { selfom }\end{array}$ & $\begin{array}{l}\text { Ineteres, } \\
\text { užitek, } \\
\text { notranje } \\
\text { zadovoljstvo }\end{array}$ \\
\hline
\end{tabular}

Na skrajnem levem koncu kontinuuma samodoločenosti se nahaja amotivacija (angl. amotivation), ki je stanje pomanjkanja namena za delovanje. Ko so ljudje amotivirani, se sploh ne odzivajo ali se odzivajo pasivno. Amotivacija se kaže v nevrednotenju dejavnosti (Ryan, 1995, v Ryan \& Deci, 2000), v občutenju nekompetentnosti pri opravljanju le-te (Bandura, 1986, v Ryan \& Deci, 2000) ali v občutku nezmožnosti dosega želenega cilja (Seligman, 1986, v Ryan \& Deci, 2004).

Naslednja zunanje motivirana vedenja označujejo štirje različni tipi motivacije:

- zunanja motivacija, ki je najmanj avtonomna, je zunanja regulacija (angl. external regulation). Ta je klasični primer motiviranja zaradi pridobivanja nagrade ali izogibanja kazni;

- introjekcijska regulacija (angl. introjected regulation) je tip zunanje motivacije, ki je delno ponotranjena, je del osebe, vendar ni del celostnega selfa. Vedenja, ki temeljijo na tej motivaciji, se opravljajo z namenom izogibanja krivdi, strahu in osramočenosti ali za dosego občutka izboljšanja ega in ponosa;

- identifikacija (angl. identified regulation) se odraža kot zavestno vrednotenje vedenjskega cilja ali regulacije in sprejema vedenje kot osebno. Ko se oseba identificira z aktivnostjo ali z vrednostjo, ki jo ta izraža, jo osebno potrdi (vsaj na zavestni ravni) (Ryan \& Deci, 2000; Ryan \& Deci, 2004);

- integrirana regulacija (angl. integrated regulation), pri kateri je aktivnost storjena z namenom določenega izida oz. rezultata in ne zaradi notranjega zadovoljstva. Vrednoti se objektivnost, zato ni nujno, da posameznik v aktivnost uživa.

Na skrajnem desnem robu kontinuuma samodoločenosti se nahaja notranja motivacija (angl. intrinsic motivation), to je aktivnost, ki jo posameznik opravlja zaradi notranjega zadovoljstva in zaradi aktivnosti same.

Indeks delovne samodoločenosti (Work self determination index - W-SDl; Vallerand, 1997) so raziskovalci uvedli z namenom združevanja notranje in zunanje motivacije v eno oceno (npr. Grolnick \& Ryan, 1987, v Vallerand, 1997; 
Vallerand \& Bissonnette, 1992). Računamo ga takrat, ko želimo izpostaviti posameznike, ki imajo izrazito avtonomno (samodoločeno) vedenje oz. izrazito neavtonomno (ne-samodoločeno) vedenje.

\subsection{Izsledki raziskav notranje in zunanje motivacije}

Začetne študije (Deci, 1975, v Ryan \& Deci, 2000) so ugotovile, da oprijemljive nagrade (npr. denar) zmanjšujejo notranjo motivacijo. Obljubljena nagrada kratkotrajno poveča motiviranost, njen učinek pa hitro oslabi in dolgoročno celo zmanjša motivacijo za nadaljevanje dela, če ni v igri še večja ponujena nagrada (Deci, 1969, v Dolenc, 2010). Notranje motivacije ne znižujejo samo oprijemljive nagrade, ampak tudi grožnje, roki, ukazi, ocene pod pritiskom in vsiljeni cilji, ki prav tako kot oprijemljive nagrade, vodijo do zunanjega zaznavanja mesta vzročnosti (Ryan \& Deci, 2000). V nasprotju pa možnost za prostovoljno izbiro in izražanje čustev povišujeta notranjo motivacijo, ker dajeta ljudem večji občutek avtonomnosti (Deci \& Ryan, 1985, v Ryan \& Deci, 2000). Deci, Kostner in Ryan (1999, v Gagné \& Forest, 2008) so ugotovili, da je bil učinek nagrad pozitiven pri verbalnih nagradah (pohvale) in negativen pri konkretnih nagradah (denar).

Prednosti notranje motivacije pa se kažejo v večji vedenjski učinkovitosti, večji vztrajnosti, povišanem življenjskem zadovoljstvu in boljši prilagoditvi posameznika v njegovi socialni skupini (Ryan et al., 1997, v Ryan \& Deci, 2000).

\subsubsection{Izsledki raziskav pri razlikovanju notranje in zunanje motivacije glede na sektor}

Zaposleni v zasebnem sektorju višje ocenjujejo višino plače in dodatke kot v javnem sektorju, vendar pa so v nasprotju s stereotipom raziskave ugotovile tudi, da med sektorjema ni nikakršnih razlik, kar se tiče pomena varnosti zaposlitve (Frank \& Lewis, 2004; Karl \& Sutton, 1998; Lewis \& Frank, 2002, v Lyons, Duxbury \& Higgins, 2006). Kasneje je Khojasteh (1993) ugotovil, da javni uslužbenci vrednotijo varnost zaposlitve nižje kot zasebni. Takšna nihanja lahko pripišemo pogojem na trgu (Karl \& Sutton, 1998, v Lyons, Duxbury \& Higgins, 2006) - v določenem času lahko vlada odpusti veliko število javnih uslužbencev, zato se pri njih posledično poviša tudi vrednota varnosti zaposlitve.

Glede zunanjih motivatorjev pri vodjih so si raziskave dokaj enotne. McClelland (1961, v Khojasteh, 1993) je v študiji vodij zaposlenih v javnem in zasebnem sektorju v ZDA, Italiji in Turčiji ugotovil, da imajo vodje v javnem sektorju večjo potrebo po dosežkih kot vodje v zasebnem sektorju. Buchannan (1979, v Khojasteh, 1993) pravi, da imajo vodje v javnem sektorju na področju dosežkov manj možnosti, da neposredno preverjajo svoj prispevek k doseganju ciljev organizacije in zato doživljajo tudi pomembno nižjo stopnjo zadovoljstva kot vodje v zasebnem sektorju (Rainey, 1979; Solomon, 1986, v Khojasteh, 1993). Vodje v zasebnem sektorju pripisujejo večjo vrednost ekonomskim nagradam, 
medtem ko vodje javnega sektorja pripisujejo večjo vrednost varnosti zaposlitve (Frankel \& Manners, 1980; Cacioppe \& Mock, 1984, v Khojasteh, 1993).

V raziskavi Lyons, Duxbury in Higgins (2006) se je pokazala statistično pomembna razlika pri dveh notranjih motivatorjih - pri intelektualni stimulaciji in pri delu, polnem izzivov. Oba notranja motivatorja so zaposleni v javnem sektorju uvrstili višje kot zaposleni v zasebnem sektorju. Zanimivo je, da pri osebnem zanimanju za delo niso našli statistično pomembnih razlik med sektorjema. Tudi S. M. Park in J. Word (2009) sta ugotovili, da so zaposleni v javnem sektorju bolj notranje motivirani kot zaposleni v zasebnem sektorju.

Večina teh študij pa je enotnega mnenja, da je največji problem obeh sektorjev pomanjkanje notranje motiviranega kadra, ki je morda nekoliko bolj kritičen v javnem kot v zasebnem sektorju.

\subsection{Zadovoljstvo z življenjem}

Subjektivno blagostanje opisuje posameznikovo vrednotenje lastnega življenja, oceno tega, kako pozitivno oziroma negativno doživlja lastno življenje (Diener, 1984). Diener in Diener (2001, v Musek \& Avsec, 2002) pravita, da subjektivno blagostanje pomeni posameznikova vrednotenja lastnega življenja in vključuje srečo, prijetne emocije, zadovoljstvo z življenjem ter relativno odsotnost neprijetnih razpoloženj ter emocij. Gre za zaznanje, da je življenje $v$ danem trenutku ali celo $v$ celoti polno, smiselno in prijetno (Myers, 1992, v Musek \& Avsec, 2002). Pomensko torej ustreza pojmu sreče in nekateri raziskovalci ga dejansko uporabljajo kot strokovni sinonim za bolj poljudni izraz sreča.

\subsubsection{Izsledki raziskav zadovoljstva z življenjem}

Številne študije navajajo povezavo med zadovoljstvom z življenjem in objektivnim prihodkom - premožnejši posamezniki so v vseh kulturah bolj zadovoljni (Diener, 2000; Easterlin, 1984, v Diener, 1984), Musek in Avsec (2002) pa dodajata, da je ta zveza relativno nizka, čeprav je pozitivna in statistično pomembna. Psihološki vidiki kakovosti življenja so pomembnejši od materialnih in socioloških.

Zadovoljstvo z življenjem pozitivno korelira z notranjo motivacijo in negativno z zunanjo (Musek, 2006). Občutje, da delujemo v skladu z vrednotami in dosegamo cilje, pozitivno vpliva na subjektivno blagostanje. Posamezniki, ki so s svojim življenjem bolj zadovoljni, dosegajo na svojem delovnem mestu višjo učinkovitost, deležni pa so tudi drugih prednosti oziroma ugodnosti, med drugim dosegajo pomembnejša, bolj avtonomna in raznovrstna delovna mesta, več zaslužijo, poleg tega na delovnem mestu kažejo manj neproduktivnih vedenj in izgorelosti kot posledice delovnih obremenitev (Lyubomirsky et al., 2005, v Dimec, Mahnič, Marinšek, Masten \& Tušak, 2008). 
Cilj pričujoče raziskave je bil ugotoviti, ali se zaposleni med seboj razlikujejo glede na vrsto motivacije in kako se različo vrste motivacije povezujejo z zadovoljstvom z življenjem.

Specifične cilje smo oblikovali okoli ključnih področij:

- opredelitev vrste motivacije zaposlenih;

- samoocena zadovoljstva z življenjem zaposlenih;

- primerjava razlik med samooceno zadovoljstva z življenjem in vrste delovne motivacije zaposlenih v javnem in zasebnem sektorju glede na spol, izobrazbo in delovno mesto.

\section{Metoda}

\subsection{Udeleženci}

V raziskavi je sodelovalo 288 zaposlenih - 186 žensk (64,6 \%) in 102 moška (35,4 \%). Povprečna starost zaposlenih je bila 36,7 let. Glede na izobrazbo je imelo 149 zaposlenih visoko strokovno ali univerzitetno izobrazbo, 109 srednjo ali višjo strokovno šolo, 28 magisterij, specializacijo ali doktorat znanosti, 2 pa na to vprašanje nista želela odgovoriti. V raziskavi je sodelovalo 67 vodij, 216 ne-vodij, 5 pa jih ni želelo podati odgovora o delovnem mestu. Glede na sektor je sodelovalo 116 zaposlenih v javnem sektorju, ki prihajajo iz petih organizacij s področja državne uprave, lokalne skupnosti in zdravstva. Vseh pet organizacij se uvršča med srednje velike organizacije (med 50 in 250 zaposlenih). 153 udeležencev pa je zaposlenih v zasebnem sektorju, pri čemer jih 83 \% prihaja iz srednje velikih ali velikih organizacij. 19 zaposlenih tega podatka ni navedlo.

\subsection{Pripomočki}

Vprašalnik zunanje in notranje delovne motivacije (Work extrinsic and intrinsic work motivation scale - WEIMS; Tremblay, Blanchard, Taylor, Pelletier \& Villeneuve, 2009) meri zunanjo in notranjo delovno motivacijo pri zaposlenih. Samoocenjevalna lestvica vsebuje 18 postavk, pri katerih zaposleni odgovarjajo na vprašanje "Zakaj opravljate svoje delo?». Pri vsaki postavki morajo na 5-stopenjski ocenjevalni lestvici oceniti, v kolikšni meri se strinjajo s postavko (1 = nikakor se ne strinjam, 5 = popolnoma se strinjam). Vprašalnik je razdeljen na šest podlestvic (notranja motivacija, integrirana regulacija, identifikacijska regulacija, introjekcijska regulacija, zunanja regulacija in amotivacija), kjer vsaka vsebuje tri postavke.

Pri rezultatu indeksa delovne samodoločenosti (W-SDI, Vallerand, 1997) je razpon možnih točk za 5-stopenjsko lestvico med \pm 24 . Končni rezultat predstavlja posameznikovo relativno stopnjo samodoločenosti. Pozitivni rezultat pomeni profil samodoločenosti, negativni pa profil nesamodoločenosti. 
Lestvica zadovoljstva z življenjem (Satisfaction with life scale - SWLS; Diener, Emmons, Larsen \& Griffin, 1985) meri posameznikovo globalno oceno kakovosti njegovega življenja glede na osebne kriterije (trajno občutje, da je življenje bilo dobro in je dobro, da je sedanji čas življenja ali celo življenje v celoti popolno, smiselno in prijetno). Samoocenjevalna lestvica vsebuje 5 postavk, ki se ocenjuje na 7-stopenjski lestvici ( 1 = sploh ne drži, 7 = popolnoma drži). Končni rezultat dobimo s seštevkom odgovorov vseh petih postavk. Lestvica je visoko zanesljiva, s koeficienti alfa od 0,85 (Pavot \& Diener, 1993) do 0,89 (Alfonso \& Allison, 1992, v Pavot \& Diener, 1993).

\subsection{Postopek}

Na posebni spletni strani so bili objavljeni oba vprašalnika in dodatna vprašanja o demografskih spremenljivkah udeležencev (spol, starost, izobrazba, delovno področje, delovno mesto). Zbiranje podatkov je potekalo od junija do julija 2010.

Podatke smo analizirali s statističnim programom SPSS. Deskriptivna statistika (srednje vrednosti, standardne deviacije) je bila izračunana za vse obravnavane spremenljivke.

T-test smo uporabili za ugotavljanje statistično pomembnih razlik med srednjima vrednostima dveh skupin. Rezultat nam je pomagal odgovoriti, ali obravnavani skupini (če so podatki razpršeni normalno) prihajata iz iste populacije, ali prihaja do razlik zaradi naključja oz. napake merjenja.

Zaradi naključnega vzorčenja znotraj sodelujočih organizacij smo uporabili tudi neparametrični Mann-Whitney $U$ test, ki je alternativa $t$-testu. Test je primeren za obravnavo, ko so odvisne spremenljivke na ordinalnem ali intervalnem nivoju, podatki pa nenormalno razpršeni. Standardizirana $z$ vrednost je približna normalni standardni deviaciji, katere pomembnost je mogoče preveriti v tabelah normalne porazdelitve.

$\checkmark$ analizo podatkov smo kot klasično mero povezanosti med dvema spremenljivkama vključili tudi Pearsonov koeficient korelacije. 


\section{Rezultati}

\subsection{Primerjava zaposlenih glede na Vprašalnik zunanje in notranje delovne motivacije}

Tabela 1: Deskriptivne statistike in mere normalnosti vseh zaposlenih $(\mathrm{N}=288)$ za posamezne tipe motivacij na Vprašalniku zunanje in notranje delovne motivacije

\begin{tabular}{|l|c|c|c|c|}
\hline & M & SD & Min & Max \\
\hline Notranja motivacija & 11,90 & 2,70 & 3 & 15 \\
\hline Integrirana regulacija & 10,88 & 2,95 & 3 & 15 \\
\hline Identifikacijska regulacija & 10,19 & 2,60 & 3 & 15 \\
\hline Introjekcijska regulacija & 8,39 & 2,93 & 3 & 15 \\
\hline Zunanja regulacija & 10,40 & 2,68 & 3 & 15 \\
\hline Amotivacija & 5,09 & 2,34 & 3 & 12 \\
\hline
\end{tabular}

V tabeli 1 vidimo, da je pri vseh zaposlenih najbolj izražena notranja motivacija, najmanj pa amotivacija. Pri vodjih v javnem in zasebnem sektorju ni prišlo do statistično pomembnih razlik na nobeni podlestvici. Pri ne-vodjih pa je prišlo do statistično pomembnih razlik le pri integrirani regulaciji, pri čemer imajo ne-vodje $v$ javnem sektorju ta tip motivacije višje izražen kot $v$ zasebnem (Mann-Whitney $U: z=-2,468, p=0,014$ ). Med zaposlenimi z različno izobrazbo nismo ugotovili nobenih razlik pri nobenem tipu motivacije.

Grafikon 1: Prikaz odstotka zaposlenih, ki prikazujejo samodoločeno oz. nesamodoločeno vedenje, glede na sektor, delovno mesto, spol in izobrazbo

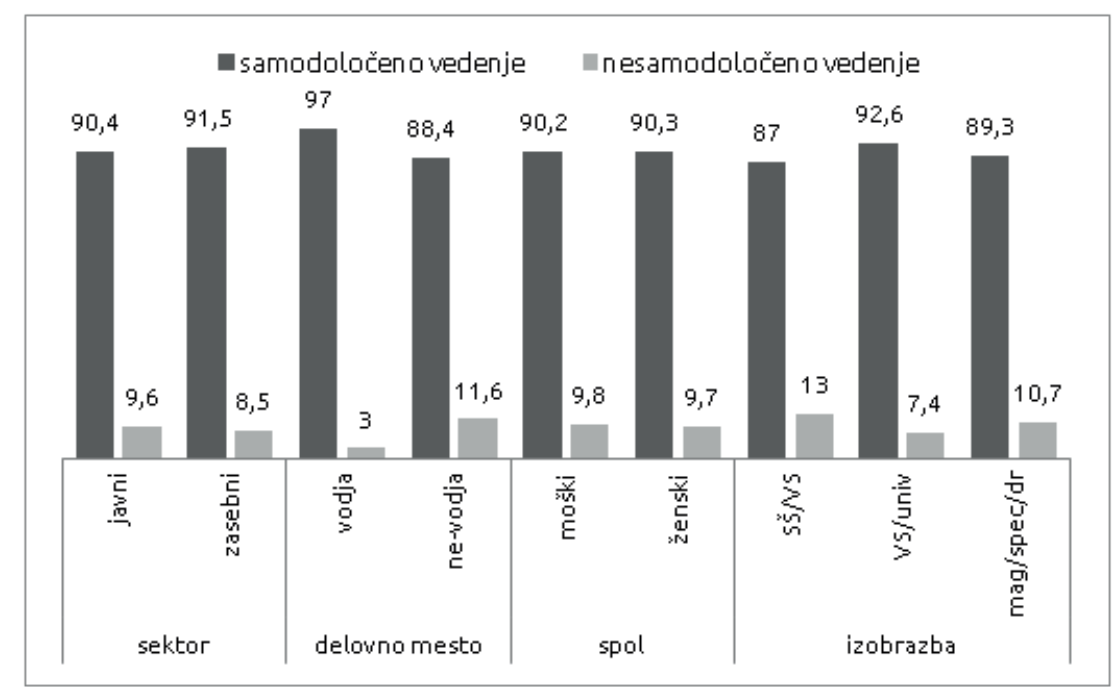

Opombe:SŠ/VS = srednja ali višje strokovna šola; VS/Univ = visoko strokovna ali univerzitetna; mag/spec/dr = magisterij ali specializacija ali doktorat znanosti 
Grafikon 1 prikazuje odstotke zaposlenih glede na to, ali se pri njih pojavlja samodoločeno ali nesamodoločeno vedenje, katerega smo izračunali z indeksom delovne samodoločenosti WSDI. Glede na sektor je odstotek več zaposlenih v zasebnem kot javnem sektorju takih, ki imajo samodoločeno vedenje. Glede na delovno mesto je več samodoločenega vedenja opaziti med vodji kot med ne-vodji. Med spoloma je izražanje samodoločenega vedenja približno enako. Glede na izobrazbo pa je največ samodoločenega vedenja med tistimi z visoko strokovno ali univerzitetno izobrazbo, najmanj pa med tistimi, ki imajo srednjo ali višjo strokovno šolo.

\subsection{Primerjava zaposlenih glede na Lestvico zadovoljstva $z$ življenjem}

Med sektorjema ni prišlo do statistično pomembne razlike v rezultatu na Lestvici zadovoljstva z življenjem.

\section{Grafikon 2: Prikaz odstotkov zaposlenih glede na sektor na Lestvici zadovoljstva z življenjem}

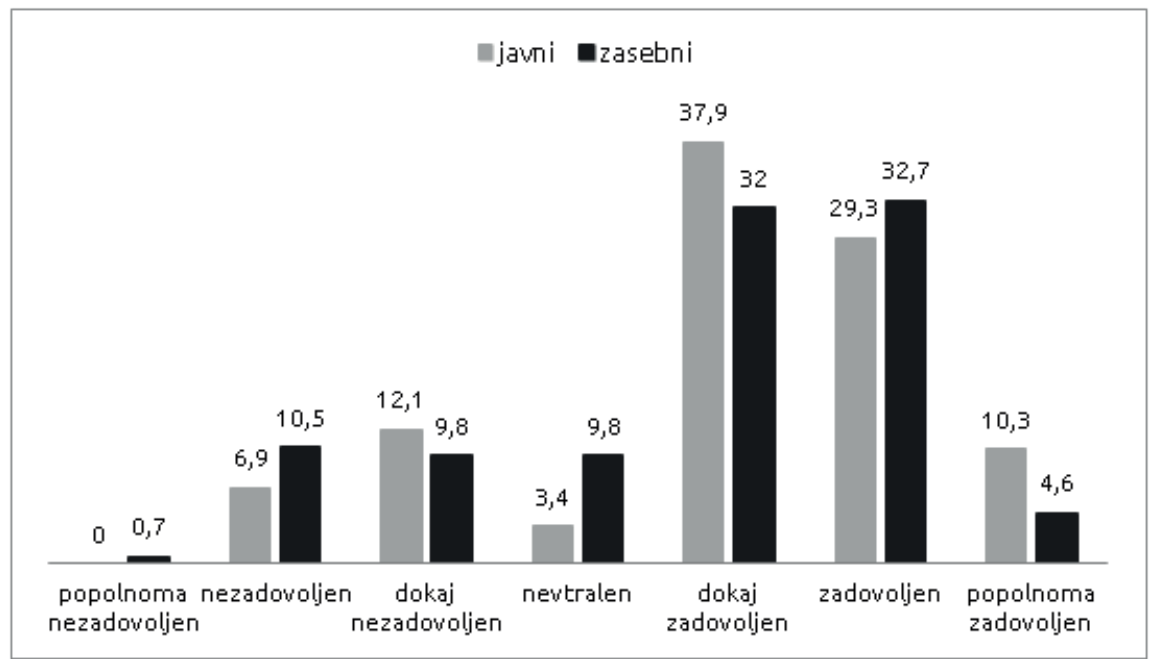

Grafikon 2 prikazuje odstotek zaposlenih glede na sektor na sedmih stopnjah Lestvice zadovoljstva z življenjem. Vidimo lahko, da je največ zaposlenih, tako v javnem kot zasebnem sektorju, »dokaj zadovoljnih« (večji odstotek je pri zaposlenih v javnem sektorju). Visok odstotek zaposlenih v obeh sektorjih je "zadovoljnih«, v zasebnem sektorju jih je celo malenkost več »zadovoljnih« kot »dokaj zadovoljnih«. V obeh sektorjih je več zaposlenih »dokaj nezadovoljnih« kot »popolnoma zadovoljnih«. »Popolnoma nezadovoljnih« v javnem sektorju ni, v zasebnem sektorju pa je takšnih 0,7\%. Tudi »nezadovoljnih« je v zasebnem sektorju več kot v javnem. Med vodji in ne-vodji v sektorjih ni prišlo do statistično pomembnih razlik v skupnem rezultatu na Lestvici zadovoljstva z življenjem. 
Grafikon 3: Prikaz odstotkov zaposlenih glede na delovno mesto na Lestvici zadovoljstva z življenjem

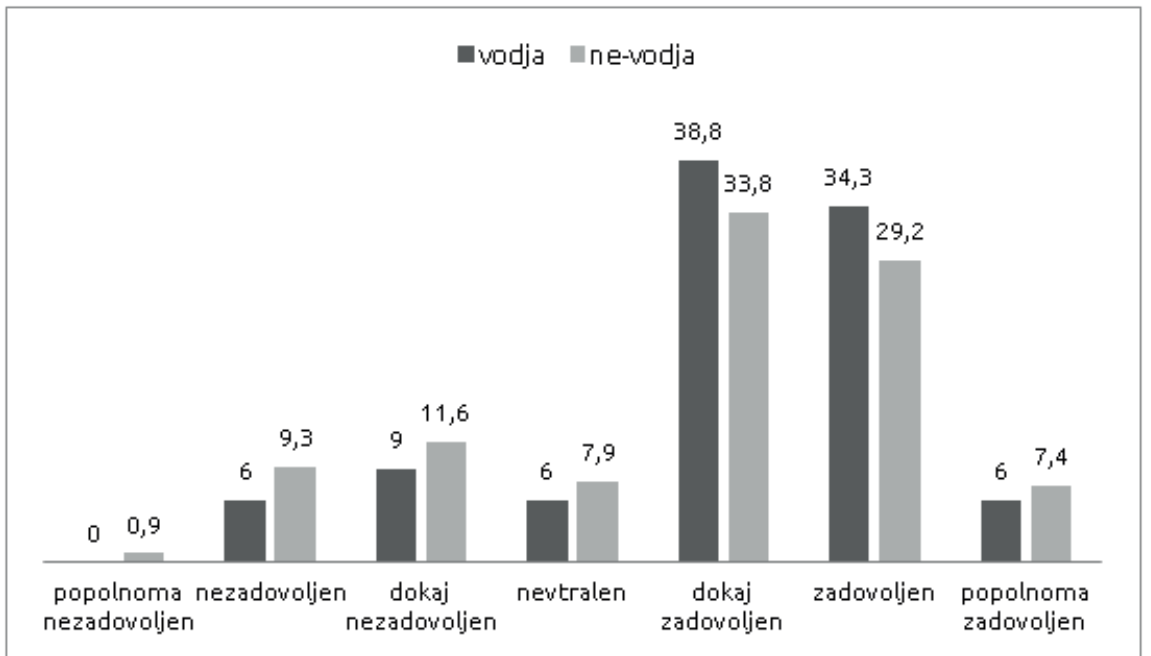

Grafikon 3 prikazuje odstotek zaposlenih glede na delovno mesto na sedmih stopnjah Lestvice zadovoljstva z življenjem. Vidimo lahko, da je največ zaposlenih, vodij in ne-vodij, »dokaj zadovoljnih« (večji odstotek je pri vodjih). Kar nekaj odstotkov zaposlenih, ki niso vodje, je »dokaj nezadovoljnih« $(11,6 \%)$ in »nezadovoljnih« $(9,3 \%)$ ter jih je več kot »nezadovoljnih« in »dokaj nezadovoljnih« vodij. Zanimivo pa je, da je nekoliko več ne-vodij bolj "popolnoma zadovoljnih« kot vodij. »Popolnoma nezadovoljnih« med vodji ni, med ne-vodji pa je takšnih 0,9 \%.

Tabela 2: Deskriptivne statistike in mere normalnosti glede na izobrazbo zaposlenih za rezultat na Lestvici zadovoljstva z življenjem

\begin{tabular}{|l|l|c|c|c|c|c|}
\hline & izobrazba & N & M & SD & Min & Max \\
\hline \multirow{3}{*}{$\begin{array}{l}\text { Zadovoljstvo } \\
\text { z življenjem }\end{array}$} & SŠ/NS & 109 & 21,82 & 5,65 & 7 & 32 \\
\cline { 2 - 7 } & VS/univ & 149 & 24,25 & 5,05 & 10 & 34 \\
\cline { 2 - 7 } & mag/spec/dr & 28 & 25,54 & 5,92 & 10 & 35 \\
\hline
\end{tabular}

Opombe:SŠ/VS = srednja ali višje strokovna šola; VS/univ = visoko strokovna ali univerzitetna; mag/spec/dr = magisterij ali specializacija ali doktorat znanosti; $M$ = aritmetična sredina; SD = standardna deviacija.

Razlike med zaposlenimi z različno izobrazbo smo preverjali s t-testom, pri čemer smo ugotovili razlike med zaposlenimi s srednjo ali višjo šolo in zaposlenimi z visoko ali univerzitetno izobrazbo, pri čemer so slednji bolj zadovoljni z življenjem $(t=1,09, p=, 018)$. 


\subsection{Primerjava zaposlenih glede na povezave med različnimi konstrukti}

Indeks delovne samodoločenosti se statistično pomembno pozitivno povezuje z zadovoljstvom z življenjem.

Tabela 3: Povezave med rezultatom na Lestvici zadovoljstva z življenjem in tipi motivacije na Vprašalniku notranje in zunanje delovne motivacije pri zaposlenih glede na sektor $\left(\mathrm{N}_{\text {javni }}=116, \mathrm{~N}_{\text {zasebni }}=153\right)$

\begin{tabular}{|l|c|c|}
\hline \multirow{2}{*}{} & \multicolumn{2}{|c|}{ Zadovoljstvo z življenjem $(r)$} \\
\cline { 2 - 3 } & Javni sektor & Zasebni sektor \\
\hline Notranja motivacija &, $317^{* *}$ &, $233^{* *}$ \\
\hline Integrirana regulacija &, 087 &, $263^{* *}$ \\
\hline Identifikacijska regulacija &, 168 &, $281^{* *}$ \\
\hline Introjekcijska regulacija &, 021 &, 124 \\
\hline Zunanja regulacija &,- 092 &, $257^{* *}$ \\
\hline Amotivacija &,$- 303^{* *}$ &,- 114 \\
\hline
\end{tabular}

** $p<, 01$

$\checkmark$ tabeli 3 lahko vidimo, da se pozitivno in statistično pomembno z zadovoljstvom z življenjem povezujejo: notranja motivacija, integrirana regulacija, identifikacijska regulacija in zunanja regulacija v zasebnem sektorju ter notranja motivacija $v$ javnem sektorju. $V$ negativni smeri in statistično pomembno se z zadovoljstvom z življenjem povezuje le amotivacija v javnem sektorju.

Tabela 4: Povezave med rezultatom na Lestvici zadovoljstva z življenjem in tipi motivacije na Vprašalniku notranje in zunanje delovne motivacije pri zaposlenih glede na delovno mesto

\begin{tabular}{|l|c|c|}
\hline \multirow{2}{*}{} & \multicolumn{2}{|c|}{ Zadovoljstvo z življenjem $(r)$} \\
\cline { 2 - 3 } & vodja & ne-vodja \\
\hline Notranja motivacija &, $309 * *$ &, $224^{* *}$ \\
\hline Integrirana regulacija &, 110 &, $227^{* *}$ \\
\hline Identifikacijska regulacija &, 198 &, $244^{* *}$ \\
\hline Introjekcijska regulacija &, 203 &, 020 \\
\hline Zunanja regulacija &, 124 &, 084 \\
\hline Amotivacija &,- 159 &,$- 249 * *$ \\
\hline
\end{tabular}

$* * p<, 01$

$\checkmark$ tabeli 4 lahko vidimo, da se z zadovoljstvom z življenjem pozitivno in statistično pomembno povezujejo naslednje motivacije: notranja motivacija, integrirana regulacija, identifikacijska regulacija pri ne-vodjih ter notranja motivacija pri vodjih. Nemotivirani ne-vodje so v primerjavi z motiviranimi z življenjem tudi manj zadovoljni. 
Julija Peklar, Eva Boštjančič

\section{Razprava}

Namen raziskave je bil preveriti, ali se zaposleni razlikujejo v vrsti delovne motivacije glede na sektor, delovno mesto, spol in izobrazbo ter kako se različni tipi motivacije povezujejo z zadovoljstvom z življenjem.

\subsection{Primerjava zaposlenih glede na Vprašalnik zunanje in notranje delovne motivacije}

Če primerjamo zaposlene glede na sektor, imajo zaposleni v zasebnem sektorju vse tipe motivacije nekoliko višje izražene kot zaposleni v javnem sektorju, hkrati so tudi bolj amotivirani od zaposlenih v javnem sektorju, vendar razlike prav tako niso statistično pomembne. Ugotovitve so bile tudi v drugih študijah deljene. Najbolj raziskovana zunanja motivatorja, plačo in varnost zaposlitve, so $v$ številnih študijah zaposleni vrednotili različno in enotnih ugotovitev ni bilo (Lewis \& Frank, 2002; Baldwin, 1991; Frank \& Lewis, 2004; Karl \& Sutton, 1998, v Lyons, Duxbury \& Higgins, 2006). Nikjer pa niso ugotovili, da se sektorja statistično pomembno ne razlikujeta pri nobenem tipu motivacije, kot se je zgodilo v našem primeru.

Če pogledamo razlike zaposlenih glede na delovno mesto in sektor, pri vodjih v javnem in zasebnem sektorju ni prišlo do statistično pomembnih razlik na nobeni podlestvici, pri zaposlenih, ki niso na vodstvenih položajih, pa je prišlo do statistično pomembnih razlik le pri integrirani regulaciji, pri čemer imajo $v$ javnem sektorju ta tip motivacije višje izražen kot v zasebnem. Pomeni, da imajo ne-vodje $v$ javnem sektorju višje izraženo motivacijo, pri kateri se zaznane regulacije popolnoma identificirajo s ponotranjenimi vrednotami, cilji in potrebami. Zaposleni sprejemajo vrednote in cilje organizacije oz. podjetja in jih popolnoma integrirajo v svoj koncept selfa, vendar aktivnosti na delu še vedno opravljajo zaradi končnega rezultata in ne lastnega zadovoljstva. Aktivnosti so že zelo blizu notranje motivacije, vendar je aktivnost še vedno opravljena z namenom določenega izida.

Grafikon 1 prikazuje odstotke zaposlenih glede na to ali se pri njih pojavlja samodoločeno ali nesamodoločeno vedenje, katerega smo izračunali z indeksom delovne samodoločenosti WSDI. Glede na delovno mesto je več samodoločenega vedenja opaziti med vodji kot med ne-vodji. Med spoloma je izražanje samodoločenega vedenja približno enako. Glede na izobrazbo pa je največ samodoločenega vedenja med tistimi z visoko strokovno ali univerzitetno izobrazbo, najmanj pa med tistimi, ki imajo srednjo ali višjo strokovno šolo. To bi lahko pomenilo, da zaposleni v javnem sektorju, vodje in zaposleni z visoko strokovno ali univerzitetno izobrazbo na delovnem mestu pogosteje dosegajo zastavljene cilje (Sheldon \& Elliot, 1998, v Gagné \& Forest, 2008), imajo boljše dosežke (Baard et al., 2004), kažejo tudi več interesa, vznemirljivosti in zaupanja, kar se izraža v večji zmogljivosti, vztrajnosti in kreativnosti (Deci \& Ryan, 1991; Sheldon, Ryan, Rawsthorne \& Ilardi, 1997, v Ryan \& Deci, 2000). Več pozitivnih izidov imajo tudi v zasebnem življenju in 
imajo tako višje splošno subjektivno blagostanje (Ilardi et al., 1993, v Gagné \& Forest, 2008; Ryan, Deci \& Grolnick, 1995, v Ryan \& Deci, 2000; Baard et al., 2004), dosegajo boljše psihološko zdravje (Deci \& Ryan, 2008) ter kažejo več vitalnosti (Nix, Ryan, Manly \& Deci, 1999, v Ryan \& Deci, 2000) in samozavesti (Deci \& Ryan, 1995, v Ryan \& Deci 2000).

\subsection{Primerjava zaposlenih glede na Lestvico zadovoljstva z življenjem}

Med sektorjema ni prišlo do statistično pomembne razlike v rezultatu na Lestvici zadovoljstva z življenjem, torej so zaposleni v obeh sektorjih enako zadovoljni s svojim življenjem (grafikon 3).

Vodje v javnem sektorju kažejo večje zadovoljstvo z življenjem kot vodje v zasebnem, čeprav razlike niso statistično pomembne, kar je nasprotno kot v raziskavah (Rainey, 1979; Rhinehart, Barrell, DeWolfe, Griffin \& Spaner, 1969; Solomon, 1986, v Khojasteh, 1993), kjer so ugotovili, da vodje v javnem sektorju doživljajo pomembno manjšo stopnjo zadovoljstva kot vodje v zasebnem sektorju.

Pri ugotavljanju razlik med zaposlenimi z različno izobrazbo smo ugotovili, da se z višanjem izobrazbe viša tudi zadovoljstvo z življenjem. Zaposleni z visoko ali univerzitetno izobrazbo in zaposleni z magisterijem, specializacijo ali doktoratom znanosti so statistično pomembno bolj zadovoljni z življenjem kot zaposleni s srednjo ali višjo šolo. Ponovno bi lahko bil vzrok temu dejstvo, da zaposleni z višjo izobrazbo več zaslužijo, hkrati pa so lahko razlogi tudi, da imajo takšni zaposleni delovna mesta z veliko več intelektualnega dela, vnašajo lahko več svojih idej, več je skupinskega dela, delo ni monotono in fizično naporno.

\subsection{Povezave med različnimi konstrukti}

V naši raziskavi nas je zanimala predvsem povezava zadovoljstva z življenjem z različnimi tipi motivacije in drugimi konstrukti, povezanimi z njo.

Pri obeh sektorjih velja, da so posamezniki, pri katerih se pojavlja samodoločeno vedenje, tudi bolj zadovoljni s svojim življenjem. Stem, ko ponotranjajo zunanje regulacije, izkusijo več avtonomnosti pri določeni aktivnosti in so posledično bolj zadovoljni s samim seboj - imajo višjo samozavest (Deci \& Ryan, 1995, v Ryan \& Deci 2000) in so potem tudi bolj zadovoljni s svojim življenjem (Ilardi et al., 1993, v Gagné \& Forest, 2008; Ryan, Deci \& Grolnick, 1995, v Ryan \& Deci, 2000; Baard et al., 2004).

Povezanost indeksa in življenjskega zadovoljstva je pozitivna in statistično pomembna. Ta povezava potrjuje, da se pri zaposlenih z visoko izraženim indeksom pojavljajo avtonomna, samodoločena vedenja, ki se povezujejo z zadovoljstvom z življenjem. 
Zanimala nas je tudi povezava zadovoljstva z življenjem in različnih tipov motivacije. Tabela 3 prikazuje te povezave glede na sektor. Vidimo lahko, da se pozitivno in statistično pomembno z zadovoljstvom z življenjem povezujejo: notranja motivacija, integrirana regulacija, identifikacijska regulacija in zunanja regulacija v zasebnem sektorju ter notranja motivacija v javnem sektorju. Zaradi različnih raziskav (npr. Kasser \& Ryan, 2001; McHoskey, 1999; Ryan et al., 1999; Schmuck, Kasser \& Ryan, 2000; Sheldon \& Kasser, 1995; Williams, Cox, Hedberg \& Deci, 2000, v Vansteenkiste, Simons, Lens, Sheldon \& Deci, 2004), ki so ugotavljale negativne življenjske izide zaposlenih z izrazitejšimi zunanjimi oblikami motivacije, smo se odločili tudi pri nas pogledati povezavo med seštevkom zunanjih motivacij (pri čemer smo po teoriji samodoločenosti sešteli integrirano regulacijo, identifikacijsko regulacijo, introjekcijsko regulacijo in zunanjo regulacijo) in zadovoljstvom z življenjem. Рri povprečju vseh zunanjih motivacij vidimo, da se le-ta pozitivno in statistično pomembno povezuje z zadovoljstvom z življenjem le v zasebnem sektorju.

Amotivacija se negativno povezuje z zadovoljstvom z življenjem pri zaposlenih $v$ obeh sektorjih, čeprav samo $v$ javnem statistično pomembno. Ti rezultati so pričakovani, saj je amotivacija popolno nasprotje notranji motivaciji, ki se pozitivno povezuje z zadovoljstvom z življenjem. Zaposleni, ki so amotivirani, se torej ne počutijo zadovoljno niti v službi niti nasploh v življenju. To je še en dokaz, kako pomembno je počutje pri delu, kako močno delo vpliva tudi na naše zasebno življenje in splošno življenjsko počutje.

Pri zaposlenih v zasebnem sektorju je zanimivo tudi to, da se z zadovoljstvom $v$ življenju statistično pomembno in pozitivno povezuje več motivacij kot pri zaposlenih v javnem - tudi integrirana regulacija, identifikacijska regulacija, zunanja regulacija in povprečje zunanjih motivacij. Pri slednjih dveh motivacijah ponovno naletimo na nepričakovan rezultat, saj bi za njiju pričakovali ravno nasprotno - negativno povezavo z zadovoljstvom z življenjem. Raziskave namreč dokazujejo, da bi naj zaposleni, ki imajo bolj izražene zunanje oblike motivacije, namreč imeli več negativnih življenjskih izidov (slabše mentalno zdravje, nižje zadovoljstvo z življenjem, nižjo samozavest, več konfliktov s prijatelji in družino, večjo potrošnjotobaka (npr. Kasser \& Ryan, 2001; McHoskey, 1999; Ryan et al., 1999; Schmuck, Kasser \& Ryan, 2000; Sheldon \& Kasser, 1995; Williams, Cox, Hedberg \& Deci, 2000, v Vansteenkiste, Simons, Lens, Sheldon \& Deci, 2004). V našem primeru pa se je izkazalo ravno nasprotno. Pri zunanji regulaciji, ki se pri zaposlenih v zasebnem sektorju torej ravno tako pozitivno in pomembno povezuje z zadovoljstvom z življenjem, se srečamo s podobnim fenomenom. Več zunanjih motivatorjev zaposleni imajo, bolj so zadovoljni z življenjem. Zaposleni v zasebnem sektorju so torej zadovoljni s svojim življenjem, če jih motivirajo notranji ali pa zunanji motivatorji. Vzroki so lahko podobni tistim, ki smo jih omenjali že pri povezavi kontrolne motivacije in zadovoljstva z življenjem pri zasebnem sektorju. Verjetno imajo ti zaposleni slabše delovne pogoje od zaposlenih v javnem sektorju in jih že zadovoljitev le-teh privede do večje sreče oz. zadovoljstva z življenjem. 
Prirazlikovanju med delovnima mestoma smo prišli do zelo podobnih rezultatov kot pri razlikovanju med sektorjema. Pri vodjih se z zadovoljstvom z življenjem pozitivno in statistično pomembno povezuje le notranja motivacija, pri nevodjih pa poleg notranje motivacije še integrirana regulacija, identifikacijska regulacija in povprečje zunanjih motivacij. Verjetno se pri njihovem odnosu do vodje pojavlja nekakšen občutek neizpolnjenih delovnih pogojev ali drugih manjvrednostnih občutkov, zaradi česar pride do tega, da so ne-vodje zadovoljni s svojim življenjem tudi ko so prisotni zunanji motivatorji.

\section{Zaključki}

Pri vseh zaposlenih smo ugotovili, da jih pri delu najbolj motivirajo notranji dejavniki, najmanj pa je takšnih, ki so pri delu amotivirani. $V$ zasebnem sektorju so zaposleni nekoliko bolj amotivirani kot v javnem, vendar razlike niso statistično pomembne. Rezultati so pokazali, da se s stopnjo izobrazbe viša notranja motiviranost. Pričakovali bi, da se z višanjem izobrazbe manjša tudi amotivacija, vendar se na našem vzorcu to ni pokazalo. Pri razlikovanju med spoloma nismo našli nobenih večjih razlik, razen pri integrirani regulaciji, ki je pri ženskah izražena nekoliko višje kot pri moških. V naši raziskavi več samodoločenega oz. avtonomnega vedenja kažejo zaposleni $v$ javnem sektorju, vodje in zaposleni z visoko ali univerzitetno izobrazbo.

Razlik pri zadovoljstvu z življenjem glede na sektor nismo ugotovili. Prav tako ni razlik med vodji in ne-vodji. Se pa povečuje zadovoljstvo z življenjem s stopnjo izobrazbe.

\subsection{Pomanjkljivosti raziskave, možnosti nadaljnjih raziskav in priporočila}

Kljub dokaj reprezentativnemu vzorcu (nekaj manj kot 300 oseb), smo glede na teorijo in raziskave s Vprašalnikom zunanje in notranje delovne motivacije pričakovali več statistično pomembnih razlik med zaposlenimi glede na sektor in delovno mesto. Vzrok je morda lahko tudi skoraj trikrat manjše število sodelujočih vodij. Kljub temu, da je odgovarjanje bilo popolnoma anonimno, nekaj zaposlenih ni želelo podati odgovorov o sektorju ali delovnem mestu. Morda bi več pozornosti lahko namenili tudi izbiranju bolj reprezentativnega vzorca. Kljub temu, da se je povezava do vprašalnikov širila po principu snežene kepe znotraj posamezne sodelujoče organizacije (s čimer smo pridobili več udeležencev, kot bi jih z osebnim iskanjem), bi pridobivanje podatkov morda moralo biti bolj ciljno. Morda bi lahko v raziskavi bolj natančno raziskali razlike glede na različna področja v javnem sektorju (zdravstvo, šolstvo, državna uprava, policija ...) in jih primerjali med sabo.

$V$ naši raziskavi smo se osredotočili zgolj na povezavo motivacije in zadovoljstva z življenjem, zanimivo pa bi bilo raziskati mogoče povezave še z delovnim zadovoljstvom, pripadnostjo organizaciji, delovnimi vrednotami, osebnostnimi lastnostmi zaposlenih, delovno učinkovitostjo, stresom ... 
Glede na to, da je tudi socialno okolje zelo pomembno pri ustvarjanju ustreznih pogojev za razvijanje notranje motivacije, je v organizacijah treba skrbeti predvsem za ustrezno klimo med nadrejenimi in podrejenimi ter med sodelavci. Treba se je osredotočati tudi na posameznike, saj se vsak posameznik različno odziva na posamezne obveznosti in spremembe v okolju, nekateri bodo bolj notranje motivirani, drugi bodo potrebovali več verbalnih vzpodbud in vodenja.

Kaj zaposlene motivira, je tema, ki bi jo bilo dobro uvesti tudi v letne in selekcijske razgovore. Vodja se mora poglabljati v spoznavanje podrejenih in ustvarjati okolje, kjer bodo različni posamezniki razvijali čim več notranje motiviranega vedenja. Dobro bi bilo, da bi se vodje in tudi drugi zaposleni izobraževali o tem, kaj sploh motivacija je. Pomembno je vedeti, da ne obstaja le deljenje na notranjo in zunanjo motivacijo in da obstaja več tipov zunanje motivacije. Zelo pomembno je, da vodja prepozna tip motivacije, ki se pojavlja pri zaposlenemu, da ga lahko, v primeru neustrezne motivacije ali celo amotivacije, ustrezno motivira, da bo dosegel stopnjo notranjega motiviranja. Glede na tip motivacije je treba ustrezno podajati navodila, naloge, ukrepe, spremembe, ideje in predstaviti prednosti notranje motiviranega vedenja ter se zavedati, kako velik vpliv ima motivacija na zadovoljstvo z življenjem in na splošno počutje zaposlenega.

Julija Peklar, univ. dipl. psih. je diplomirala novembra leta 2010 na Filozofski fakulteti v Ljubljani. V zadnjem letniku študija je opravljala obvezno študijsko prakso na Ministrstvu za visoko šolstvo, znanost in tehnologijo, kjer si je nabrala veliko dodatnih znanj in izkušenj. Trenutno je zaposlena v Slovenski vojski na delovnem mestu psihologa.

Dr. Eva Boštjančič je diplomirala s področja psihologije potrošnika leta 1996. Zaposlila se je kot svetovalka na kadrovskem področju, vzporedno pa se je na raziskovalnem področju usmerila k raziskovanju procesa vodenja in čustvene inteligentnosti. Leta 2002 je magistrirala z nalogo Osebnostne značilnosti uspešnih managerjev, 2008 pa si je z dizertacijo Vpliv vedenja in motivov vodje na pripadnost, delovno učinkovitost, motivacijo in delovno zadovoljstvo zaposlenih pridobila naziv doktorice znanosti. Leta 2003 je pridobila naziv asistentke, leta 2011 naziv docentke za področje psihologije dela in organizacije na ljubljanski Filozofski fakulteti. Vzporedno je pridobila številne izkušnje kot svetovalka na področju kadrovskega svetovanja. 


\section{Literatura in viri}

- Baard, P. P. (2004). Intrinsic Need Satisfaction in Organizations: A Motivational Basis of Success in For-profit and Not-for-Profit Settings. V Deci, E. L. \& Ryan, R. M. (ur.). Handbook of Self-Determination Research (255-276). Rochester, New York: The University of Rochester Press.

- Deci, E. L. \& Ryan, R. M. (2000). The "What" and "Why" of Goal Pursuits: Human Needs and the Self-Determination of Behavior. Psychological Inquiry 11(4), 227-268.

- Deci, E. L. \& Ryan, R. M. (2008). Self-Determination Theory: A Macrotheory of Human Motivation, Development, and Health. Canadian Psychology 49(3), 182-185.

- Diener, E. (1984). Subjective Well-Being. Psychological Bulletin 95(3), 542-575.

- Diener, E., Emmons, R. A., Larsen, R. J. \& Griffin, S. (1985). The Satisfaction With Life Scale. Journal of Personality Assessment 49(1), 71-75.

- Diener, E. (2000). Subjective Well-Being: The Science of Happiness and a Proposal for a National Index. American Psychologist 55(1), 34-43.

- Dimec, T., Mahnič, J., Marinšek, M., Masten, R. \& Tušak, M. (2008). Zadovoljstvo z življenjem in delovno zadovoljstvo zaposlenih v Slovenski vojski. Psihološka obzorja 17(4), 117-130.

- Dolenc, S. (2010). Ali nagrajevanje zavira inovativnost? Pridobljeno 18. 9. 2010, s http://www.kvarkadabra.net/article.php/Ali-nagrajevanje-zavira-inovativnost.

- Državni portal Republike Slovenije (2010). Ljubljana. Pridobljeno 29. 9. 2010, s http://e-uprava.gov.si/ispo/stran.ispo?pageTo=osistemu.jsp

- Gagné, M. \& Deci, E. L. (2005). Self-determination theory and work motivation. Journal of Organizational Behavior 26, 331-362.

- Gagné, M. \& Forest, J. (2008). The study of compensation systems through the lens of self-determination theory: Reconciling 35 years of debate. Canadian Psychology 49(3), 225-232.

- Khojasteh, M. (1993). Motivating the Private vs. Public Sector Managers. Public Personnel Management 22(3), 391-401.

- Lyons, S. T., Duxbury, L. E. \& Higgins, C. A. (2006). A Comparison of the Values and Commitment of Private Sector, Public Sector, and Parapublic Sector Employees. Public administration review 66(4), 605-618.

- Ministrstvo za javno upravo (2010). Spletna stran: http://www.mju.gov.si/.

- Musek, J. (2006). Humanistični in pozitivni psihološki model osebnosti. Študijsko gradivo (prosojnice iz predavanj Psihologija osebnosti). Ljubljana: Filozofska fakulteta, Oddelek za psihologijo.

- Musek, J. \& Avsec, A. (2002). Pozitivna psihologija: Subjektivni (emocionalni) blagor in zadovoljstvo z življenjem. Anthropos 1-3, 41-68.

- Park, S. M. \& Word, J. (2009). Motivated to Serve: Constructs and Consequences of Work Motivation for Public and Nonprofit Managers. Članek predstavljen leta 2009 na konferenci International Public Service Motivation (IPSM) Research Conference, Bloomington, Indiana. Pridobljeno 17. 6. 2010, s http://www.indiana.edu/ ipsm2009/Park_Word.pdf.

- Pavot, W. \& Diener, E. (1993). Review of the Satisfaction with Life Scale. Psychological Assessment 5(2), 164-172.

- Ryan, R. M. \& Deci, E. L. (2000). Self-determination theory and the facilitation of intrinsic motivation, social development and well-being. American Psychologist 55(1), 66-78. 
Julija Peklar, Eva Boštjančič

- Ryan, R. M. \& Deci, E. L. (2004). Overview of Self-Determination Theory: An Organismic Dialectical Perspective. V Deci, E. L. \& Ryan, R. M. (ur.). Handbook of Self-Determination Research (3-33). Rochester, New York: The University of Rochester Press.

- Tremblay, M. A., Blanchard, C. M., Taylor, S., Pelletier, L. G. \& Villeneuve, M. (2009). Work Extrinsic and Intrinsic Motivation Scale: Its Value for Organizational Psychology Research. Canadian Journal of Behavioural Science 41(4), 213-226.

- Uhan, S. (2000). Vrednotenje dela II. Motivacija, uspešnost, plača (osebni dohodek). Kranj: Moderna organizacija.

- Vallerand, R. J. \& Bissonnette, R. (1992). Intrinsic, Extrinsic, and Amotivational Styles as Predictors of Behavior: A Prospective Study. Journal of Personality 60(3), 599-620.

- Vallerand, R. J. (1997). Toward A Hierarchical Model of Intrinsic and Extrinsic Motivation. V Zanna ,M. P. (ur.). Advances in Experimental Social Psychology 29 (271-360). San Diego, CA: Academic.

- Vansteenkiste, M., Simons, J., Lens, W., Sheldon, K. M. \& Deci, E. L. (2004). Motivating Learning, Performance, and Persistence: The Synergistic Effects of Intrinsic Goal Contents and Autonomy-Supportive Contexts. Journal of Personality and Social Psychology 87(2), 246-260. 